Review Article

\title{
LONG-TERM IMMUNOLOGICAL CONSEQUENCES OF COVID-19 ON HEALTH
}

\author{
HARSHADA KADAM*, GAURI KAPHARE, RUPALI AVHAD, PRAJWAL AHER, NIKHIL GADE, MANOJ BAJAIT, SWATI \\ TALELE, ANIL JADHAV
}

Department of Pharmaceutics, Sandip Institute of Pharmaceutical Sciences, Mahiravani, Nashik 422213, Maharashtra, India

Email: harshadak987@gmail.com

Received: 05 Jun 2021, Revised and Accepted: 16 Aug 2021

\begin{abstract}
SARS-Cov-2 (severe acute respiratory syndrome coronavirus) that initially came to notice in December 2019 is the agent responsible for COVID-19 is still spreading rapidly worldwide and it is presently a potent danger to the world and also to the economy. Patients with COVID-19 are still at risk of Acute Respiratory Distress Syndrome (ARDS), respiratory failure, and death. Those patients whose aged more than sixty years with comorbidities, children, and healthcare workers are highly vulnerable to this virus patient shows various symptoms most commonly cough, fever, difficulty in breathing, fatigue, sore throat. The infection could be categorized into three stages: mild infection, the pulmonary stage, and the inflammatory stage. As the COVID-19 pandemic continues, it has been clear that infection caused due to SARS-Cov-2 might be responsible for the unpredicted long-term health consequences. In addition to this, it has acute respiratory manifestations, adversely SARS-Cov-2 also affects the other organ systems. However, there is limited to the management of COVID-19 related conditions of the extrapulmonary systems. After recovery, patients remain at risk for lung disease, heart disease, and mental ailment. There may be long-term consequences of adverse effects they observed in the course of COVID-19 and during its treatment. This review provided information about the extrapulmonary manifestations of COVID-19 that may impair the urinary, cardiovascular, gastrointestinal, hematological, hematopoietic, neurological, or reproductive systems. Also, the main purpose of this article is to describe the current concern of the extra pulmonary complications that were caused due to COVID-19 and also to improve the management and diagnosis of these patients.
\end{abstract}

Keywords: COVID-19, Treatment, Extra-pulmonary manifestation, Management, SARS-Cov-2

(c) 2022 The Authors. Published by Innovare Academic Sciences Pvt Ltd. This is an open access article under the CC BY license (https://creativecommons.org/licenses/by/4.0/) DOI: https://dx.doi.org/10.22159/ijap.2022v14i1.42311. Journal homepage: https://innovareacademics.in/journals/index.php/ijap

\section{INTRODUCTION}

The spread of coronavirus disease 2019 (COVID-19) was mainly caused by severe acute respiratory syndrome coronavirus-2 (SARSCoV-2), lately, it has become a global pandemic and public health problem in all countries [1-3]. Coronavirus infections are responsible for severe and life-threatening acute respiratory syndromes in humans. As per the report of $16^{\text {th }}$ June 2020 , more than 7900000 confirmed cases come out and approximately 434796 total deaths for COVID-19 have been reported globally. The evolution of vaccines is an early stage, also the increasing number of infected patients is rapidly worldwide. In addition to the common acute respiratory symptoms (such as fever, cough, and dyspnea), also COVID-19 patients have shown signs and symptoms of injury to other organ systems, which may make difficult medical management. COVID-19 affects the upper airways (sinuses, nose, throat) and lower airways (windpipe, lungs). The virus enters into host cells through the enzyme angiotensin-converting enzyme 2 (ACE2) due to this lungs are the most affected organ by COVID-19, which is most profuse in type-II alveolar cells of the lungs [4]. The virus makes use of a particular surface glycoprotein called a "spike" (peplomer) that connects to ACE2 and enters into the host cell [4]. The density of ACE2 in each tissue match up with the seriousness of the disease in that tissue and some have suggested decreasing ACE2 activity might be protective, [5] though another view is that increasing ACE2 using angiotensin II receptor blocker medications could be protective [6]. As the alveolar disease progression, respiratory failure might evolve and death may occur [7].

\section{SARS-CoV-2 and the immune system}

SARS-CoV-2 belonging to the coronavirus family caused two epidemics at the beginning of the $21^{\text {st }}$ century; one was named SARS-CoV-2, and the second is Middle East Respiratory Syndrome (MERS).

Coronavirus is large enveloped viruses with a positive-sense RNA genome. The spike (S) has two S1 and S2 domains, which are responsible for invasion, attachment, and entry into human cells. The receptor-binding domain in S1 interconnects with angiotensin- converting enzyme 2 on the human host cell surface, which is a similar entry mechanism to SARS-CoV; however, the S2 domain is responsible for virus-cell membrane fusion and viral entry with higher affinity [8]. Higher manner of the ACE2 receptor in adults as compared to children may be the reason for higher infection in adults as compared to children $[9,10]$. As increased the extent of enzymes in the liver, heart, and kidneys of COVID-19 patients with pneumonia; this could also responsible for the multiple organ failure in some of the patients [11]. Therefore, these organs constitute the main target for the virus.

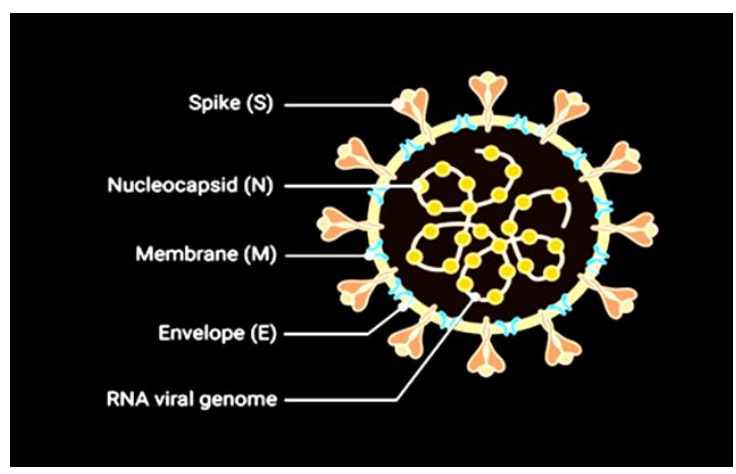

Fig. 1: Structure of coronavirus (self-modified)

\section{Symptoms}

Large number of patients suffers from common cold and flu when infected with this virus, although some maybe asymptomatic. About $80 \%$ of patient will show mild symptoms are shown in about $80 \%$ of the patient with this. It is observed that adults having greatest immunity to fight against this infection but the disadvantage is they rapidly spread the infection. In $99 \%$ of patients shows fever with seriously high temperature, while remaining patients will 
experience fatigue, dry cough. In One-third of patient dry cough, difficulty in breathing observed. From day 1 to day 17 various symptoms of COVID-19 given below they goes from bad to worse.

Day 1: In the first day fever together with, muscle pain, dry cough, fatigue are observed. In some patients nausea and diarrhea observed.

Day 5: Few Patients experienced difficulty in breathing particularly in elderly patients having earlier health condition.

Day 7: On the day $7^{\text {th }}$ patients need to be admitted in the hospital.

Day 8: Patients develop ARDS is develop by patients in this the fluid fills up into lungs and this is mostly fatal. Usually happens in severe cases.

Day 10: Worsening of the symptom if the disease is in progression and at this movement the patient is shifted to ICU. Percent of death is very less.

Day 17: After two-and-a-half weeks patients who recover are discharged from hospital. Although, it is strenuous to find out symptoms in early stages of infection. Commonly observed after 5-6 d.

\section{Covid-19 death rate due to medical conditions}

Information made by Centers for Disease Control and Prevention (CDC) and other studies shows that death rate is more in old age people and the people who do not having the good medical conditions. People with serious illness, such as diabetes, heart, lungs disease, have a greater risk. Death rate is $1 \%$ of those who have no history of medical conditions. Death rate is $10.5 \%$ for those who suffer from cardiovascular diseases, death rate is $7.3 \%$ for those who suffer from diabetes, death rate is $6.3 \%$ for people who suffer from Chronic respiratory disease (such as asthma and chronic obstructive pulmonary disease), death rate is $6.0 \%$ for people suffering from hypertension and death rate is $5.6 \%$ for people suffering from cancer.

\section{Treatments}

Allopathic treatment and management comprise oxygen therapy, drug treatment, and intravenous fluid infusion using life support in hazardous cases. Coronavirus may demonstrate comparable proteins for virus reproduction in the human immunodeficiency virus (HIV). Therefore, HIV protease inhibitors and nucleoside derivatives may be efficacious to treat COVID-19 like combination therapy of lopinavir. A minute ago, an Italian patient of COVID-19 was treated by making a combination of lopinavir $(200 \mathrm{mg})$ and ritonavir $(50 \mathrm{mg})$ twice a daytime, in Sawai Man Singh (SMS) Hospital, Jaipur India. Equally well, the patient has also presented a combination of oseltamivir and chloroquine drug. The patient gets recovered and the test was found negative for COVID-19. Some drugs are in clinical trial and outcomes are still expected. The best methodology to fight with viruses is vaccination. Consequently, scientists are trying to cultivate a vaccine for this virus and undoubtedly may be available later some time. Existing clinical indication does not support preventing angiotensin-converting enzyme inhibitors or angiotensin receptor blockers in patients with COVID-19 [12,13].

\section{Anti-viral drugs}

Drugs that come under this category typically follow either of the next three mechanisms the ion channel blocking agent, virus-viral replication inhibition, and serine protease inhibition. In the market existing antiviral drugs typically target the four primary groups of viruses: herpes, hepatitis, human immunodeficiency virus (HIV), and flu. Previous outbreak incidents of viral infections like SARS-CoV and MERS-CoV as well as hemorrhagic fever viruses like Ebola were managed with this category of drugs only $[14,15]$.

\section{Anti-malarial drugs}

It comes under three groups grounded on their antifolate compound, mode of action aryl amino-alcohol compound, and artemisinin. Maximum of these drugs are eradicated progressively from the body enduring for long periods after consumption. The disadvantage of these drugs is that antimalarial drug resistance cultivates for any drugs below this category $[16,17]$.

\section{Anti-HIV drugs}

These drugs are categorized into diverse groups grounded on their targets retro-transcription, reverse transcription, viral-cell fusion, proteolytic processing, and combination of proviral DNA into the host genome and co-receptors interactions. Drugs that come under in these groups have been permitted by the FDA (Food and Drug Administration) and are nowadays publicly used for the treatment of HIV.

\section{Anti-inflammatory drugs}

Enormous inflammatory response is detected in COVID-19. Antiinflammatory drugs, particularly JAK-STAT inhibitors are used in contradiction of rheumatoid arthritis, may be operational against raising levels of cytokines, and valuable in preventing viral infection. Rendering to the latest study, an inflammatory drug, baricitinib is when applied in combination with means of anti-viral drugs like Remdesivir, it increases the effectiveness of the drug to decrease viral infection $[18,19]$.

\section{Monoclonal antibodies}

The virus is known to occur in the host cells by binding the $S$ protein to ACE2 receptors. By emerging neutralizing antibodies in contradiction of the sense organs, there is a high probability of decreasing the harshness of the disease. Presently, only a few of drugs have been sanctioned for usage against SARS-CoV-2 [20].

\section{other clinically used drugs}

Even earlier the announcement of COVID-19 as a pandemic by WHO, there was an enormous lack of disease precise drugs. Due to promptly increasing virus, it is important to make available appropriate treatment for the affected patients [21].

\section{Ribavirin}

Ribavirin is one of the broad-spectrum drugs whose therapeutic potential was revealed in 1972. This antiviral drug is used to treat hepatitis C. It is typically used with interferon $\alpha$ (IFN). This medicine is, approved by the USFDA, it plays for the active site of RdRp [22].

\section{Sofosbuvir}

This drug is also FDA approved drug in contradiction of NS5B and target as a nucleotide polymerase inhibitor applied for the treatment of hepatitis C. It was applied in combination with interferon or RBV. This drug was earlier applied for the treatment of the Zika virus [23].

\section{Lopinavir/Ritonavir}

Lopinavir/Ritonavir is a protease inhibitor, which objects the HIV. It was acknowledged by 1998 and approved by the USFDA by 2000 . This drug blocks the formation of viral proteins by disturbing the proteolytic treatment by mimicking its structure as a peptide cleaved by HIV protease. Ritonavir along with another flu drug, like oseltamivir was described to result in the whole recovery after displaying signs of COVID-19 associated pneumonia [24].

\section{Remdesivir (anti-viral peptide)}

This specific drug is an adenosine nucleotide analog, which was applied to treat in contradiction of SARS-CoV, MERS-CoV, and Ebola [94]. It is a favorable and potential drug that roots premature cessation by entering the nascent viral RNA. Currently, it is undertaking clinical trials for Ebola treatment. An additional, recent study has to show that Remdesivir scored $0.77 \mu \mathrm{M}$ at half-maximal concentration beside COVID-19 and obstructed viral infection [25].

\section{Chloroquine}

This drug, which comes under an anti-malarial drug, has exhibited potential in the treatment of avian influenza A. Chloroquine also has revealed the potential to possess anti-viral and immune-modulating properties. Chloroquine showed $1.13 \mu \mathrm{M}$ at the half-maximal concentration in contradiction of SARS-CoV-2 and obstructed viral infection with an increase in endosomal $\mathrm{pH}$ mandatory for viral fusion [26]. 


\section{Vitamin D}

The vitamin D supplementation for treating of COVID-19 is used to boost your immune function. The vitamin D deficiency affects the respiratory immune function that increases the chances of COVID-19 could potentially protect against COVID-19 infection. Thus improvement in immunity through better nutrition is good factor. Thus the nutrients used as vitamin D they shows a significant role in immune function.

Table 1: Approved allopathy drugs used for the treatment of the COVID-19

\begin{tabular}{|c|c|c|c|}
\hline S. No. & Drug name & Disease treated & References \\
\hline 1. & Remdesivir & MERS,SARS COVID-19 & [68] \\
\hline 2. & Flavinavir & COVID-19 & [69] \\
\hline 3. & Lopinavir & MERS and SARS COVID-19 & [70] \\
\hline 4. & Influenza drug & MERS & [71] \\
\hline 5. & Acyclovir & MERS, SARS and COVID-19 & [72] \\
\hline 6. & Reverse transcriptase Inhibitor & SARS & [72] \\
\hline 7. & Tocilizumab & COVID-19 & [72] \\
\hline 8. & Oseltamivir & COVID-19 & [72] \\
\hline 9. & Azvudine & COVID-19 & [72] \\
\hline 10. & Carfilzomib & COVID-19 & [72] \\
\hline 11. & Indinavir & COVID-19 and SARS & [73] \\
\hline 12. & Baricitinib & COVID-19 & [74] \\
\hline 13. & Chloroquine & Coronavirus OC 43 SARS & {$[75,76]$} \\
\hline 14. & Alcohol Inhalation therapy & COVID-19 & [77] \\
\hline 15. & Ritonavir+Lopinavir & MERS, SARS & [72] \\
\hline 16 & RNA dependent RNA Polymerase & Murine Coronavirus, SARS & [78] \\
\hline 17 & Papain like protease & MERS and SARS & [79] \\
\hline 18 & Fusion inhibitors i.e. Lamivudine adefovir dipivoxil etc. & SARS & [80] \\
\hline 19 & Protease Inhibitors: saquinavir, ritonavir, indinavir, lopinavir, etc & SARS & [81] \\
\hline 20 & Nucleotide reverse transcriptase inhibitors: tenofovir disoproxil fumarate & SARS & [82] \\
\hline
\end{tabular}

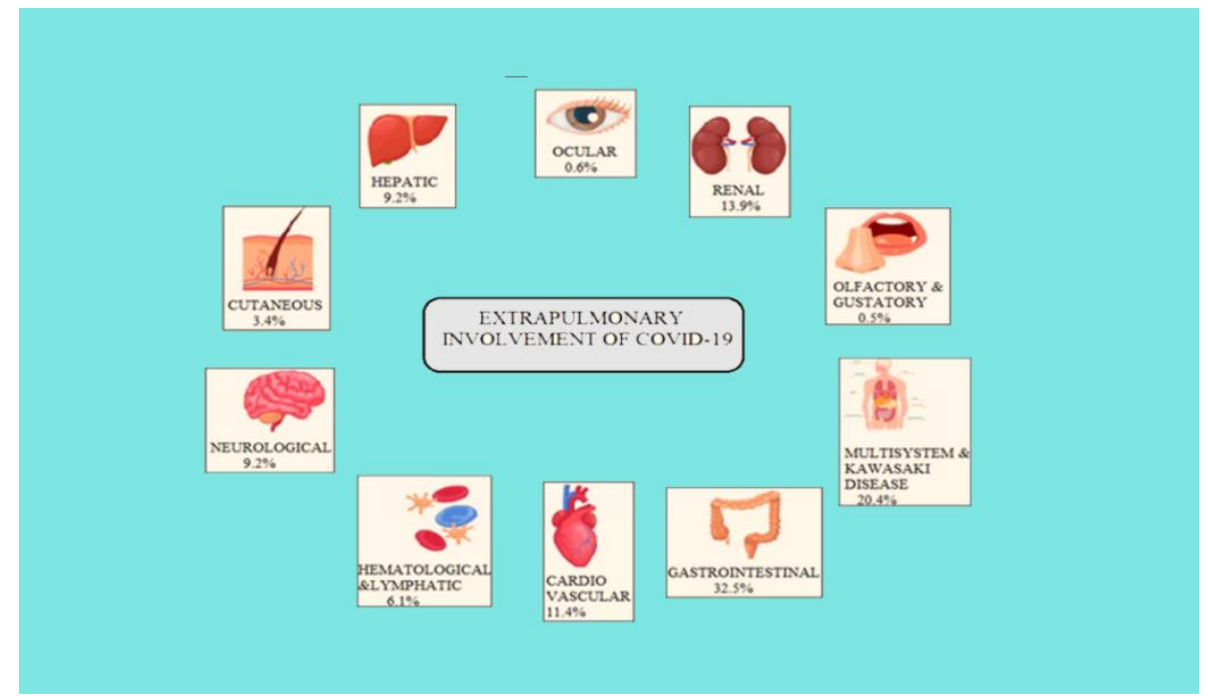

Fig. 2: Extrapulmonary involvement of COVID-19 (Self-modified)

\section{Longterm immunological consequences LUNGS}

One of the most common possible consequences of SARS-Cov-2 involved severe acute inflammation includes scarring or fibrosis, which may be irreparable and lead to long-term health problems. In the lungs may cause pulmonary fibrosis, leaving patients breathless with a reduced lung capacity. In one study, $94 \%$ of hospitalized patients showed residual abnormalities on CT scans at the time of discharge following severe COVID-19. These studies were slight but indicate that it will be necessary to follow by COVID-19 survivors to determine the lung function abnormalities are persistent, and how they should be managed.

\section{Acute kidney injury and renal failure}

The kidneys are most commonly affected extrapulmonary organs in a patient infected with SARS-CoV-2 especially, in those patients who are critically ill [27-29]. SARS outbreak has revealed that kidney damage was mainly characterized by acute tubular necrosis and increased serum creatinine and urea nitrogen concentrations [30, 31]. A recent study of 59 patients infected with SARS-CoV-2 showed mild proteinuria that was the ordinary kidney abnormality in these patients. In addition, just about $30 \%$ of these patients also had raised urea nitrogen levels and about $20 \%$ had raised serum creatinine levels [32].

Data from 138 COVID-19 patients from Zhongnan Hospital in Wuhan, China, showed that AKI occurred in $8.3 \%$ of patients was admitted to ICU vs $2 \%$ in non-ICU patients. In another study, the occurrence of AKI in 58 critically ill COVID-19 patients was as high as $29 \%$, and AKI was also found to be an important risk factor for increased hospital mortality [43].

In series Covid-19 cases, 85 patients with severe SARS-CoV-2 infection, AKI occurred in $23(27.1 \%)$ patients [34]. According to this report the SARS-CoV-2 might directly infect kidney tubules. Although the primary virologic mechanisms are not completely 
known also it is possible to assume that there is binding between virus and ACE 2 receptor, which highly appears in kidney tubules due to this causes glomerulopathy, acute tubular necrosis, and leakage of protein in the Bowman's capsule $[35,36]$. However, it was possible to assume that AKI could be an epiphenomenon of both respiratory distress syndrome-induced hypoxia and septic shock caused by the SARS-CoV-2 [37]. Other autopsy investigations have been reported that the endothelium is affected in the kidneys, and is responsible for proteinuria [49]. SARS-CoV-2 particles in renal endothelial cells may suggest that viremia is the possible cause of renal endothelial damage that resulting in AKI [34]. More recently, Sun et al. [38] have reported the occurrence of subclinical AKI as reflected by elevated urinary levels of $\beta 2$-microglobulin, $\alpha 1$-microglobulin, $\quad \mathrm{N}$-acetyl- $\quad \beta$-D-glycosaminidase, and retinol-binding protein (i.e., all biomarkers of kidney tubular damage) in a sample of 32 confirmed COVID-19 cases without prior chronic kidney disease [50]. In addition, the severity of kidney tubular damage was also greater in severe COVID-19 patients than in less severely affected patients [45]. Based on the available evidence, we can conclude the following considerations: (a) AKI is not uncommon in patients with COVID-19, especially in those with severe COVID-19; patients can present with proteinuria early or at hospital admission, while AKI often develops in later stages of the viral disease (i.e., critically ill patients) and is observed as an early sign of multiple organ dysfunction; (b)AKI can be related to the virus-related complications like asphyxia and shock; (c) the precise incidence of AKI in SARS-CoV-2 infected patients is not known; however, it is reasonable to assume that AKI is more common in critically ill patients than in those with mild COVID-19 disease; and (d) COVID-19 patients have a prior history of chronic kidney disease are more probable to develop AKI; and (e) COVID-19 patients with AKI have a poorer chance of recovery.

\section{Heart diseases}

\section{Myocardial injury}

According to the study of SARS-CoV-2 infected patients, patients were quarantined at the Tongji Hospital, Wuhan, China between January to February 2020, including 24 patients who were critically ill and 126 patients who were severely ill, Chen et al. [27] reported that approximately $20 \%$ of these patients had exhibit signs of myocardial injury as showed by increases in plasma N-terminal pro-B-type natriuretic peptide (NT-proBNP) and cardiac troponin I (cTnI) levels [11]. Also, in a retroactive study of 52 critically ill COVID-19 patients, $15(29 \%)$ of these patients had shown elevated cTnI levels (i.e., $>28 \mathrm{pg} / \mathrm{ml}$ ) [29]. There is an estimated $12 \%$ of COVID-19 patients without pre-existing or known ischemic heart disease had elevated troponin levels and also cardiac arrest during hospitalization [54]. Particularly, cTnI levels were shown to be above the $99 \%$ upper normal limit in $46 \%$ of non-survivors, as compared to $1 \%$ of survivors [39]. The rise in cTnI levels together with pro-inflammatory markers, such as interleukin-6, lactate dehydrogenase (LDH), and D-dimer, might be indicative of cytokine storm or secondary hemophagocytic lymph histiocytosis, in addition to isolated myocardial injury. Although it is uncertain whether SARS-CoV-2 may directly damage myocardial tissue and induce a major cardiovascular event, it is currently recommended that physicians should regularly monitor plasma cTnI and NT-proBNP levels in all COVID-19 patients. However, longer-term follow-up studies of these infected patients determined by cardiac function parameters (by using a transthoracic echocardiographic examination) are needed.

\section{Cardiac arrhythmias}

After the myocardial injury, arrhythmia is another cause of cardiac involvement in COVID-19 patients that fluctuate from tachycardia to bradycardia and asystole. According to the study of 121 COVID-19 patients showed that most of these patients had shown cardiac arrhythmia, including 87 (71.9\%) with sinus tachycardia unrelated to fever, $18(14.9 \%)$ with bradycardia, and one patient with paroxysmal atrial fibrillation [40]. In another study has shown that cardiac arrhythmias occurred in $23(16.7 \%)$ of 138 patients with SARS-CoV-2 infection, especially among those admitted to the ICU [28]. Another interesting observation was made among the vasoplegic population have low systemic vascular resistance in the
Wuhan cohort, where a higher proportion of critically ill COVID-19 patients and non-survivors had increased blood pressure values, which might contribute to arrhythmia, potentially explaining the pathological activity of SARS-CoV-2 infection [34, 58]. However, due to the retrospective nature of these data, it is difficult to find the cause of this observed hypertension is due to physiological reactions to the viral illness, or it is a consequence of virus-induced derangements in ACE2 expression. Overall, this indicated that arrhythmia may be an important complication among patients with SARS-CoV-2 infection. These findings suggest that especially in patients with severe COVID-19, routine electrocardiogram monitoring is needed to closely monitor patients for paroxysmal tachycardias and pulse accelerations that do not match the patient's condition [42].

\section{Sudden cardiac death}

According to the study involving 99 patients infected with SARS-CoV-2 quarantined at the Wuhan Jinyintan Hospital, China, were $(11 \%)$ deaths occurs due to sudden cardiac arrest among the patients without a previous history of ischemic heart disease [28]. These results suggest that the cause of death might be caused mainly by an imbalance of the pulmonary ventilation-perfusion ratio and a decrease in the capacity of the pulmonary vasculature. While acute myocarditis might contribute to heart failure and some investigators have been reported depressed left ventricular ejection fraction due to COVID-19, the majority of COVID-19 patients with uncomplicated lymphocytic myocarditis had normal cardiac function $[33,34]$. The pathophysiologic factors possibly involved a) occlusion of microvasculature b) depletion in the number of functional residual gas, which leads to increased resistance to the pulmonary vessel that resulting in subsequent pulmonary hypertension and cor pulmonale. Cardiac dysfunction is caused due to direct virus infection or systemic inflammation which might potentially cause coronary micro-circulation disruption and downstream myocardial ischemic consequence, but the relationship between SARS-CoV-2 infection and heart failure remains unclear. It is important to be aware of this condition to try and prevent cardiac arrest (especially in those patients who have a previous history of ischemic heart disease), so that appropriate prevention may be taken to lower the risk of death.

\section{Liver dysfunction}

In liver dysfunction described the liver function tests, such as serum transaminases, bilirubin, LDH, and prothrombin time (PT), were notably higher in COVID-19 patients who were admitted to ICU compared to non-ICU patients. In a study of 138 critically ill COVID-19 patients without a history of chronic liver diseases, who were admitted to ICU. Also, there is mild to moderate elevations of serum liver enzymes (mostly increased serum transaminases) were reported in a large multicenter Chinese study of 1099 COVID-19 patients [36]. In clinical practice, the liver function test results of patients with mild SARS-CoV-2 infection were relatively common. Instead of patients with severe (but non-critically ill) SARS-CoV-2 infection had mild to moderate elevations of serum transaminase and LDH levels [35]. Jaundice was noticed only in a few SARS-CoV-2 infected patients, who were died during hospital admission; however, hypoalbuminemia and a longer PT were also observed amongst patients who afterward died. Liver failure has also been observed with other organ failures in non-survivors of SARS-CoV-2 infection and thus, it is not easy at this time to express the excess risk of death caused due to liver failure alone [38].

The current proof suggests that liver injury occurs more frequently among those patients who were seriously ill with COVID-19, who have other co-existing causes of liver damage, such as the use of potentially hepatotoxic therapies and the co-existence of systemic inflammatory response, respiratory distress syndrome-induced hypoxia, and multiple organ dysfunction [31].

Several studies showed that in patients with chronic liver diseases, $[47,48]$ especially in those with pre-existing cirrhosis, $[49,50]$ there is an increased risk of greater COVID-19 illness and in-hospital mortality, which suggests specialized intervention strategies in these patients might help avoid a worse outcome. 
Management of liver transplant recipients has remained a challenge for physicians during the COVID-19 outbreak. It is admitted that transplant recipients are more susceptible to SARS-CoV2 infection, are more probably to have increased severity of illness, and prolonged viral shedding $[51,52]$. The patient eventually did not be rescued due to septic shock as a result of multiple infections, possibly worsened by corticosteroid treatment (for the chronic rejection). Another reason for a post-transplant patient who successfully recovered from COVID-19 developed nosocomial infections, almost like the previous case [54].

However, early discontinuation of immunosuppressive therapy (tacrolimus and mycophenolate) was analogous with recovery. In addition, SARS-CoV-2 infection during the perioperative period may additionally represent an opportunistic infection to those patients who were treated with immunosuppressive drugs to prevent acute graft rejection, and thus, it is advised to delay the scheduled transplantation procedure. However, there was a reported case where a patient who had COVID-19 before liver transplantation, recovered from COVID-19, $60 \mathrm{~d}$ after transplantation related to a lowered dosage of immunosuppressant agents [55]. Immoderate immune suppression can lead to secondary infections, in comparison to acute graft rejection.

\section{Neurological complications}

\section{Neurological symptoms}

Very little information is accessible on the possible adverse effects of SARS-CoV-2 infection on the neurological system. The signs and symptoms caused by the SARS-CoV-2 infection on the neurological system can be categorized into three types: (a) Central nervous system shows, such as dizziness, headache, disturbance and consciousness, acute cerebrovascular disease, and epilepsy; (b) peripheral nervous system shows neuralgia and loss in taste, smell, and appetite; and (c) skeletal muscle injury. In a retroactive study of 214 patients diagnosed with SARS-CoV-2; 78 of these patients had shown some neurological symptoms, accounting for $36.4 \%$ of all confirmed COVID-19 patients [56]. Patients with severe COVID-19 were developed neurological symptoms, such as acute cerebrovascular disease, impaired consciousness, and skeletal muscle injury $[56,57]$.

\section{Psychological disorders}

The psychological effects include post-traumatic stress, confusion, and anger are observed throughout quarantine during an infectious outbreak and are well noticed [58,59]. After the three years of the SARS epidemic that happened in 2013, two studies have been reported that are i)alcohol abuse or ii) dependency symptoms, as long-term effects were observed during quarantined in healthcare workers [60, 61]. Increased avoidance behaviors also have been reported to common in healthcare workers after quarantine, like observed avoiding direct contact with patients and absence of mind at work, were found significantly associated with an increase in the duration of the quarantine.

\section{Factors influencing psychological disorders}

Several factors may cause psychological disorders during quarantine.

Like the history of psychiatric illness was found to be closely related to anxiety and anger with those patients who were concerned to release from quarantine [62]. Healthcare workers appeared severe symptoms of post-traumatic stress as compared to non-healthcare workers after quarantined [63]. After quarantine some healthcare workers also felt increased levels of guilt, having more avoidance behaviors, a higher loss in income, and felt more negatively affected psychologically. The various psychological effects include increased worry, anger, fear, frustration, guilt, isolation, loneliness, and nervousness. Though one study showed that a cut-off of $10 \mathrm{~d}$ of quarantine duration influenced the outcome of psychological impact, [64] it is generally accepted that a longer duration of quarantine is more likely to induce poorer psychological outcomes and mental health conditions $[60,63,64]$. Other factors like fear, [62] adverse reactions to imprisonment or isolation, [65] lack of sufficient information from authorities (regarding well-being and duration of quarantine), and terror of the financial loss.

\section{CONCLUSION}

Due to the COVID-19 pandemic global crisis has been arise. On the human health as the long term health issues has been observed. Also the health care workers faces the psychological complications, like loneliness, avoidance behavior. Due to the all of this complication we need to take care from Covid-19. And maintaining the social distance and always wear mask whenever going to outside.

\section{ABBREVIATION}

SARS-CoV-Severe acute respiratory syndrome coronavirus, ARDSAcute respiratory distress syndrome, ACE2-Angiotensin-converting enzyme 2, MERS-Middle east respiratory syndrome, RNARibonucleic acid, AKI-Acute kidney injury, NT-proBNP-N-terminal pro-B-type natriuretic peptide, LDH-lactate dehydrogenase, PTProthrombin time.

\section{FUNDING}

Nil

\section{AUTHORS CONTRIBUTIONS}

All the authors have contributed equally.

\section{CONFLICT OF INTERESTS}

Declared none

\section{REFERENCES}

1. Li Q, Guan X, Wu P, Wang X, Zhou L, Tong Y, Ren R, Leung KSM, Lau EHY, Wong JY, Xing X, Xiang N, Wu Y, Li C, Chen Q, Li D, Liu T, Zhao J, Liu M, Tu W, Chen C, Jin L, Yang R, Wang Q, Zhou S, Wang R, Liu H, Luo Y, Liu Y, Shao G, Li H, Tao Z, Yang Y, Deng Z, Liu B, Ma Z, Zhang Y, Shi G, Lam TTY, Wu JT, Gao GF, Cowling BJ, Yang B, Leung GM, Feng Z. Early transmission dynamics in Wuhan, China, of novel coronavirus-infected pneumonia. $\mathrm{N}$ Engl J Med. 2020;382(13):1199-207. doi: 10.1056/ NEJMoa2001316, PMID 31995857.

2. Zhang C, Shi L, Wang FS. Liver injury in COVID-19: management and challenges. Lancet Gastroenterol Hepatol. 2020;5(5):42830. doi: 10.1016/S2468-1253(20)30057-1, PMID 32145190.

3. Zhu N, Zhang D, Wang W, Li X, Yang B, Song J, Zhao X, Huang B, Shi W, Lu R, Niu P, Zhan F, Ma X, Wang D, Xu W, Wu G, Gao GF, Tan W. A novel coronavirus from patients with pneumonia in China, 2019. N Engl J Med. 2020;382(8):727-33. doi: 10.1056/NEJMoa2001017.

4. Letko M, Marzi A, Munster V. Functional assessment of cell entry and receptor usage for SARS-CoV-2 and other lineage B betacoronaviruses. Nat Microbiol. 2020;5(4):562-69. doi: 10.1038/s41564-020-0688-y, PMID 32094589.

5. Rodríguez Puertas R. ACE2 activators for the treatment of COVID 19 patients. J Med Virol. 2020;92(10):1701-2. doi: 10.1002/jmv.25992, PMID 32379346.

6. Gurwitz D. Angiotensin receptor blockers as tentative SARS-CoV-2 therapeutics. Drug Dev Res. 2020;81(5):537-40. doi: 10.1002/ddr.21656, PMID 32129518.

7. Gibson PG, Qin L, Puah SH. COVID-19 acute respiratory distress syndrome (ARDS): clinical features and differences from typical pre- COVID -19 ARDS. Med J Aust. 2020;213(2). doi: $10.5694 / \mathrm{mja} 2.50674$.

8. Cuykx M, Mortele O, Jansens H, Schouwers S, Meskal A, Hoffbauer I, Peeters B. Serological response in health care workers after a single dose of SARS-CoV-2 vaccine using six automated SARS-CoV-2 antibody assays. Diagn Microbiol Infect Dis. 2021;101(2):115486. doi: 10.1016/j.diagmicrobio.2021.115486.

9. Jia HP, Look DC, Shi L, Hickey M, Pewe L, Netland J, Farzan M, Wohlford-Lenane C, Perlman S, McCray PB. ACE2 receptor expression and severe acute respiratory syndrome coronavirus infection depend on differentiation of human airway epithelia. J Virol. 2005;79(23):14614-21. doi: 10.1128/JVI.79.23.1461414621.2005, PMID 16282461.

10. Rezaei N. COVID-19 affects healthy pediatricians more than pediatric patients. Infect Control Hosp Epidemiol. 2020;41(9):1106-7. doi: 10.1017/ice.2020.139, PMID 32297847. 
11. Chen N, Zhou M, Dong X, Qu J, Gong F, Han Y, Qiu Y, Wang J, Liu Y, Wei Y, Xia J, Yu T, Zhang X, Zhang L. Epidemiological and clinical characteristics of 99 cases of 2019 novel coronavirus pneumonia in Wuhan, China: a descriptive study. Lancet. 2020;395(10223):507-13. doi: 10.1016/S0140-6736(20) 30211-7, PMID 32007143.

12. Al-Tawfiq JA, Al-Homoud AH, Memish ZA. Remdesivir as a possible therapeutic option for the COVID-19. Travel Med Infect Dis. 2020;34:101615. doi: 10.1016/j.tmaid.2020.101615.

13. Kapoor K, Sanawedwala A, Rajput D, Bhardwaj S, Shrivastav K, Dhingra N. Current drug repurposing strategies in treatment ofCOVID-19. Int J ChemTech Res. 2020;13(3):125-31. doi: 10.20902/IJCTR.2019.130309.

14. Mitjà $\mathrm{O}$, Clotet $\mathrm{B}$. Use of antiviral drugs to reduce COVID-19 transmission. Lancet Glob Health. 2020;8(5):e639-40. doi: 10.1016/S2214-109X(20)30114-5, PMID 32199468.

15. Gautret P, Lagier JC, Parola P, Hoang VT, Meddeb L, Mailhe M, Doudier B, Courjon J, Giordanengo V, Vieira VE, Tissot Dupont H, Honore S, Colson P, Chabriere E, La Scola B, Rolain JM, Brouqui P, Raoult D. Hydroxychloroquine and azithromycin as a treatment of COVID-19: results of an open-label nonrandomized clinical trial. Int J Antimicrob Agents. 2020;56(1):105949. doi: 10.1016/j.ijantimicag.2020.105949.

16. Jaffe S. Regulators split on antimalarials for COVID-19. Lancet. 2020;395(10231):1179. doi: 10.1016/S0140-6736(20)308175, PMID 32278373.

17. Touret F, de Lamballerie X. Of chloroquine and COVID-19. Antiviral Res. 2020;177:104762. doi: 10.1016/ j.antiviral.2020.104762.

18. Zhang W, Zhao Y, Zhang F, Wang Q, Li T, Liu Z, Wang J, Qin Y, Zhang X, Yan X, Zeng X, Zhang S. The use of anti-inflammatory drugs in the treatment of people with severe coronavirus disease 2019 (COVID-19): the perspectives of clinical immunologists from China. Clin Immunol. 2020;214:108393. doi: $10.1016 /$ j.clim.2020.108393.

19. Cao X. COVID-19: immunopathology and its implications for therapy. Nat Rev Immunol. 2020;20(5):269-70. doi: 10.1038/s41577-020-0308-3, PMID 32273594.

20. Shanmugaraj B, Malla A, Phoolcharoen W. Emergence of novel coronavirus 2019-nCoV: need for rapid vaccine and biologics development. Pathogens. 2020;9(2):148. doi: 10.3390/ pathogens9020148, PMID 32098302.

21. Kebede T, Kumar D, Sharma PK. Potential drug options for treatment of COVID-19: a review. Coronaviruses. 2020;1(1):428. doi: 10.2174/2666796701999200701131604.

22. Khalili JS, Zhu H, Mak NSA, Yan Y, Zhu Y. Novel coronavirus treatment with ribavirin: groundwork for an evaluation concerning COVID-19. J Med Virol. 2020;92(7):740-6. doi: 10.1002/jmv.25798, PMID 32227493.

23. Elfiky AA. Ribavirin, Remdesivir, Sofosbuvir, Galidesivir, Tenofovir against SARS-CoV-2. RNA dependent RNA polymerase (RdRp): A molecular docking study. Life Sci. 2020;253:117592. doi: 10.1016/j.lfs.2020.117592.

24. Lim J, Jeon S, Shin HY, Kim MJ, Seong YM, Lee WJ, Choe KW, Kang YM, Lee B, Park SJ. The author's response: case of the index patient who caused tertiary transmission of coronavirus disease 2019 in Korea: the application of lopinavir/ritonavir for the treatment of COVID-19 pneumonia monitored by quantitative RT-PCR. J Korean Med Sci. 2020;35(7):e89. doi: 10.3346/jkms.2020.35.e89, PMID 32080993.

25. Grein J, Ohmagari N, Shin D, Diaz G, Asperges E, Castagna A, Feldt T, Green G, Green ML, Lescure FX, Nicastri E, Oda R, Yo K, Quiros Roldan E, Studemeister A, Redinski J, Ahmed S, Bernett J, Chelliah D, Chen D, Chihara S, Cohen SH, Cunningham J, D’Arminio Monforte A, Ismail S, Kato $H$, Lapadula G, L'Her E, Maeno T, Majumder S, Massari M, MoraRillo M, Mutoh Y, Nguyen D, Verweij E, Zoufaly A, Osinusi AO, DeZure A, Zhao Y, Zhong L, Chokkalingam A, Elboudwarej E, Telep L, Timbs L, Henne I, Sellers S, Cao H, Tan SK, Winterbourne L, Desai P, Mera R, Gaggar A, Myers RP, Brainard DM, Childs R, Flanigan T, Castagna A. Compassionate use of remdesivir for patients with severe covid-19. N Engl J Med. 2020;382(24):2327-36. doi: 10.1056/NEJMoa2007016, PMID 32275812.
26. Beigel JH, Tomashek KM, Dodd LE, Mehta AK, Zingman BS, Kalil AC, Hohmann E, Chu HY, Luetkemeyer A, Kline S, Lopez de Castilla D, Finberg RW, Dierberg K, Tapson V, Hsieh L, Patterson TF, Paredes R, Sweeney DA, Short WR, Touloumi G, Lye DC, Ohmagari N, Oh MD, Ruiz Palacios GM, Benfield T, Fätkenheuer G, Kortepeter MG, Atmar RL, Creech CB, Lundgren J, Babiker AG, Pett S, Neaton JD, Burgess TH, Bonnett T, Green M, Makowski M, Osinusi A, Nayak S, Lane HC, ACTT-1 Study Group Members. Remdesivir for the treatment of covid-19final report. New England J Medicine. 2020;383(19):1813-26. doi: 10.1056/NEJMoa2007764, PMID 32445440.

27. Wang D, Hu B, Hu C, Zhu F, Liu X, Zhang J, Wang B, Xiang H, Cheng Z, Xiong Y, Zhao Y, Li Y, Wang X, Peng Z. Clinical characteristics of 138 hospitalized patients with 2019 novel coronavirus-infected pneumonia in Wuhan, China. JAMA. 2020;323(11):1061-9. doi: 10.1001/jama.2020.1585, PMID 32031570.

28. Yang X, Yu Y, Xu J, Shu H, Xia J, Liu H, Wu Y, Zhang L, Yu Z, Fang M, Yu T, Wang Y, Pan S, Zou X, Yuan S, Shang Y. Clinical course and outcomes of critically ill patients with SARS-CoV-2 pneumonia in Wuhan, China: a single-centered, retrospective, observational study. Lancet Respiratory Medicine. 2020;8(5):475-81. doi: 10.1016/S2213-2600(20)30079-5, PMID 32105632.

29. Hui DS, Memish ZA, Zumla A. Severe acute respiratory syndrome vs. the Middle East respiratory syndrome. Current Opinion in Pulmonary Medicine. 2014;20(3):233-41. doi: 10.1097/MCP.0000000000000046, PMID 24626235.

30. Joob B, Wiwanitkit V. Novel Middle East respiratory syndrome and renal failure. Renal Failure. 20132014;36(1):147. doi: 10.3109/0886022X.2013.832316, PMID 24028462.

31. Shereen MA, Khan S, Kazmi A, Bashir N, Siddique R. COVID-19 infection: Origin, transmission, and characteristics of human coronaviruses. J Advanced Research. 2020;24:91-8. doi: 10.1016/j.jare.2020.03.005, PMID 32257431.

32. He L, Zhang Q, Li Z, Shen L, Zhang J, Wang P, Wu S, Zhou T, Xu Q, Chen X, Fan X, Fan Y, Wang N. Incorporation of urinary neutrophil gelatinase-associated lipocalin and computed tomography quantification to predict acute kidney injury and in-hospital death in COVID-19 patients. Kidney Dis. 2020:1-11. doi: 10.1159/000511403.

33. Diao B, Wang C, Wang R, Feng Z, Zhang J, Yang H, Tan Y, Wang H, Wang C, Liu L, Liu Y, Liu Y, Wang G, Yuan Z, Hou X, Ren L, Wu $Y$, Chen Y. Human kidney is a target for novel severe acute respiratory syndrome coronavirus 2 infection. Nature Communications. 2021;12(1):2506. doi: 10.1038/s41467-02122781-1, PMID 33947851.

34. Fan C, Lu W, Li K, Ding Y, Wang J. ACE2 expression in kidney and testis may cause kidney and testis infection in COVID-19 patients. Frontiers in Medicine (Lausanne). 20212020;7:563893. doi: 10.3389/fmed.2020.563893, PMID 33521006.

35. Su H, Yang M, Wan C, Yi LX, Tang F, Zhu HY, Yi F, Yang HC, Fogo $\mathrm{AB}$, Nie X, Zhang C. Renal histopathological analysis of 26 postmortem findings of patients with COVID-19 in China. Kidney International. 2020;98(1):219-27. doi: 10.1016/j.kint.2020.04.003, PMID 32327202.

36. Ronco C, Reis T. Kidney involvement in COVID-19 and rationale for extracorporeal therapies. Nature Reviews Nephrology. 2020;16(6):308-10. doi: 10.1038/s41581-020-0284-7, PMID 32273593.

37. Sun DQ, Wang TY, Zheng KI, Targher G, Byrne CD, Chen YP, Zheng MH. Subclinical acute kidney injury in COVID-19 patients: A retrospective cohort study. Nephron. 2020;144(7):347-50. doi: 10.1159/000508502, PMID 32454505 .

38. Zhou F, Yu T, Du R, Fan G, Liu Y, Liu Z, Xiang J, Wang Y, Song B, Gu X, Guan L, Wei Y, Li H, Wu X, Xu J, Tu S, Zhang Y, Chen H, Cao B. Clinical course and risk factors for mortality of adult inpatients with COVID-19 in Wuhan, China: a retrospective cohort study. Lancet. 2020;395(10229):1054-62. doi: 10.1016/S0140-6736(20)30566-3, PMID 32171076.

39. Yu C.M, Wong RS, Wu EB, Kong SL, Wong J, Yip GW, Soo YO, Chiu ML, Chan YS, Hui D, Lee N, Wu A, Leung CB, Sung JJ. Cardiovascular complications of severe acute respiratory syndrome. Postgraduate Medical Journal. 2006;82(964):14044. doi: 10.1136/pgmj.2005.037515, PMID 16461478. 
40. Ruan Q, Yang K, Wang W, Jiang L, Song J. Correction to: Clinical predictors of mortality due to COVID-19 based on an analysis of data of 150 patients from Wuhan, China. Intensive Care Medicine. 2020;46(6):1294-7. doi: 10.1007/s00134-02006028-z, PMID 32253449.

41. Yaroshchuk NA, Kochmasheva VV, Vakhrameev AV. Cardiac complications in patients with severe COVID-19 pneumonia. Med Alphabet. 2021;5(5):14-7. doi: 10.33667/2078-56312021-5-14-17.

42. Ammirati E, Cipriani M, Moro C, Raineri C, Pini D, Sormani P, Mantovani R, Varrenti M, Pedrotti P, Conca C, Mafrici A, Grosu A, Briguglia D, Guglielmetto S, Perego GB, Colombo S, Caico SI, Giannattasio C, Maestroni A, Carubelli V, Metra M, Lombardi C, Campodonico J, Agostoni P, Peretto G, Scelsi L, Turco A, Di Tano G, Campana C, Belloni A, Morandi F, Mortara A, Ciro A, Senni M, Gavazzi A, Frigerio M, Oliva F, Camici PG, Registro Lombardo delle Miocarditi. Clinical presentation and outcome in a contemporary cohort of patients with acute myocarditis: Multicenter Lombardy Registry. Circulation. 2018;138(11):1088-99. doi: 10.1161/ CIRCULATIONAHA.118.035319, PMID 29764898.

43. Liu Y, Yang Y, Zhang C, Huang F, Wang F, Yuan J, Wang Z, Li J, Feng C, Zhang Z, Wang L, Peng L, Chen L, Qin Y, Zhao D, Tan S, Yin L, Xu J, Zhou C, Jiang C, Liu L. Clinical and biochemical indexes from 2019-nCoV infected patients linked to viral loads and lung injury. Science China Life Sciences. 2020;63(3):36474. doi: 10.1007/s11427-020-1643-8, PMID 32048163.

44. Hu Y, Li Y, Jiang F, Shao T, Hu B, Zhu J, Lai C, Yu W. Efficacy and safety of first-line therapeutic drugs with potential for the treatment of novel coronavirus pneumonia: A meta-analysis. SSRN Journal. 2020. doi: 10.2139/ssrn.3627255.

45. Feng G, Zheng KI, Yan QQ, Rios RS, Targher G, Byrne CD, Poucke SV, Liu WY, Zheng MH. COVID-19 and liver dysfunction: current insights and emergent therapeutic strategies. Journal of Clinical and Translational Hepatology. 2020;8(1):1-7:18-24. doi: 10.14218/JCTH.2020.00018, PMID 32274342.

46. Gao F, Zheng KI, Wang XB, Yan HD, Sun QF, Pan KH, Wang TY, Chen YP, George J, Zheng MH. Metabolic associated fatty liver disease increases coronavirus disease 2019 disease severity in nondiabetic patients. Journal of Gastroenterology and Hepatology. 20202021;36(1):204-7. doi: 10.1111/jgh.15112, PMID 32436622.

47. Zhou YJ, Zheng KI, Wang XB, Sun QF, Pan KH, Wang TY, Ma HL, Chen YP, George J, Zheng MH. Metabolic-associated fatty liver disease is associated with severity of COVID-19. Liver International. 2020;40(9):2160-3. doi: 10.1111/liv.14575, PMID 32573883.

48. Gao F, Zheng KI, Fan YC, Targher G, Byrne CD, Zheng MH. ACE2: A linkage for the interplay between COVID-19 and decompensated cirrhosis. American Journal of Gastroenterology. 2020;115(9):1544. doi: 10.14309/ ajg.0000000000000780, PMID 32694292.

49. Qi X, Liu Y, Wang J, Fallowfield JA, Wang J, Li X, Shi J, Pan H, Zou S, Zhang H, Chen Z, Li F, Luo Y, Mei M, Liu H, Wang Z, Li J, Yang H, Xiang H, Li X, Liu T, Zheng MH, Liu C, Huang Y, Xu D, Li X, Kang N, He Q, Gu Y, Zhang G, Shao C, Liu D, Zhang L, Li X, Kawada N, Jiang Z, Wang F, Xiong B, Takehara T, Rockey DC, COVID-Cirrhosis-CHESS Group. Clinical course and risk factors for mortality of COVID-19 patients with pre-existing cirrhosis: a multicentre cohort study. Gut Gutjnl 2021;70(2):433-6. doi: 10.1136/gutjnl-2020-321666, PMID 32434831.

50. Gao F, Zheng KI, Gu JY, George J, Zheng MH. COVID-19 and liver transplantation: Lessons learned from three reported cases. Transplant Infectious Disease. 2020;22(4):e13335. doi: 10.1111/tid.13335, PMID 32438464.

51. Huang JF, Zheng KI, George J, Gao HN, Wei RN, Yan HD, Zheng MH. Fatal outcome in a liver transplant recipient with COVID-19. American Journal of Transplantation. 2020;20(7):1907-10. doi: 10.1111/ajt.15909, PMID 32277591.

52. Fishman JA, Grossi PA. Novel coronavirus-19 (COVID-19) in the immunocompromised transplant recipient: \#Flatteningthecurve. American Journal of Transplantation. 2020;20(7):1765-7. doi: 10.1111/ajt.15890, PMID 32233057.

53. Liu B, Wang Y, Zhao Y, Shi H, Zeng F, Chen Z. Successful treatment of severe COVID-19 pneumonia in a liver transplant recipient. American Journal of Transplantation. 2020;20(7):1891-95. doi: 10.1111/ajt.15901, PMID 32243673.

54. Qin J, Wang $\mathrm{H}$, Qin X, Zhang P, Zhu L, Cai J, Yuan Y, Li H. Perioperative presentation of COVID-19 disease in a liver transplant recipient. Hepatology. 2020;72(4):1491-3. doi: 10.1002/hep.31257, PMID 32220017.

55. Mao L, Jin H, Wang M, Hu Y, Chen S, He Q, Chang J, Hong C, Zhou Y, Wang D, Miao X, Li Y, Hu B. Neurologic manifestations of hospitalized patients with coronavirus disease 2019 in Wuhan, China. JAMA Neurology. 2020;77(6):683-90. doi: 10.1001/jamaneurol.2020.1127, PMID 32275288.

56. Herman C, Mayer K, Sarwal A. Scoping review of prevalence of neurologic comorbidities in patients hospitalized for COVID-19.

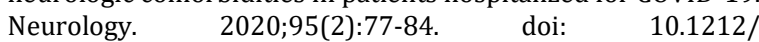
WNL.0000000000009673, PMID 32345728.

57. Brooks SK, Webster RK, Smith LE, Woodland L, Wessely S, Greenberg N, Rubin GJ. The psychological impact of quarantine and how to reduce it: rapid review of the evidence. SRN Electronic Journal Lancet. 2020;395(10227):912-20. doi: 10.1016/S0140-6736(20)30460-8, PMID 32112714.

58. Wu P, Fang Y, Guan Z, Fan B, Kong J, Yao Z, Liu X, Fuller CJ, Susser E, Lu J, Hoven CW. The psychological impact of the SARS epidemic on hospital employees in China: exposure, risk perception, and altruistic acceptance of risk. The Canadian Journal of Psychiatry. 2009;54(5):302-11. doi: $10.1177 / 070674370905400504$, PMID 19497162.

59. Marjanovic Z, Greenglass ER, Coffey S. The relevance of psychosocial variables and working conditions in predicting nurses' coping strategies during the SARS crisis: an online questionnaire survey. International Journal of Nursing Studies. 2007;44(6):991-8. doi: 10.1016/j.ijnurstu.2006.02.012, PMID 16618485.

60. Wu P, Liu X, Fang Y, Fan B, Fuller CJ, Guan Z, Yao Z, Kong J, Lu J, Litvak IJ. Alcohol abuse/dependence symptoms among hospital employees exposed to a SARS outbreak: table 1. Alcohol Alcohol. 2008;43(6):706-12. doi: 10.1093/alcalc/agn073, PMID 18790829: table 1.

61. Jeong H, Yim HW, Song YJ, Ki M, Min JA, Cho J, Chae JH. Mental health status of people isolated due to middle East respiratory syndrome. Epidemiology and Health. 2016;38:e2016048. doi: 10.4178/epih.e2016048, PMID 28196409.

62. Reynolds DL, Garay JR, Deamond SL, Moran MK, Gold W, Styra R. Understanding, compliance and psychological impact of the SARS quarantine experience. Epidemiology and Infection. 2008;136(7):997-1007. doi: 10.1017/S0950268807009156, PMID 17662167.

63. Hawryluck L, Gold WL, Robinson S, Pogorski S, Galea S, Styra R. SARS control and psychological effects of quarantine, Toronto, Canada. Emerging Infectious Diseases. 2004;10(7):1206-12. doi: 10.3201/eid1007.030703, PMID 15324539.

64. Cava MA, Fay KE, Beanlands HJ, McCay EA, Wignall R. The experience of quarantine for individuals affected by SARS in Toronto. Public Health Nursing. 2005;22(5):398-406. doi: 10.1111/j.0737-1209.2005.220504.x, PMID 16229732.

65. Maunder RG, Lancee WJ, Balderson KE, Bennett JP, Borgundvaag B, Evans S, Fernandes CM, Goldbloom DS, Gupta M, Hunter JJ, McGillis Hall L, Nagle LM, Pain C, Peczeniuk SS, Raymond G, Read N, Rourke SB, Steinberg RJ, Stewart TE, VanDeVelde-Coke S, Veldhorst GG, Wasylenki DA. Long-term psychological and occupational effects of providing hospital healthcare during SARS outbreak. Emerging Infectious Diseases. 2006;12(12):1924-32. doi: 10.3201/eid1212.060584, PMID 17326946.

66. Desclaux A, Badji D, Ndione AG, Sow K. Accepted monitoring or endured quarantine? Ebola contacts" perceptions in Senegal. Social Science and Medicine. 2017;178:38-45. doi: 10.1016/j.socscimed.2017.02.009, PMID 28192745.

67. Gormley M, Aspray TJ, Kelly DA. COVID-19: mitigating transmission via wastewater plumbing systems. The Lancet Global Health. 2020;8(5):e643. doi: 10.1016/S2214109X(20)30112-1, PMID 32213325.

68. Wang Y, Zhou F, Zhang D, Zhao J, Du R, Hu Y, Cheng Z, Gao L, Jin Y, Luo G, Fu S, Lu Q, Du G, Wang K, Lu Y, Fan G, Zhang Y, Liu Y, Ruan S, Liu W, Jaki T, Hayden FG, Horby PW, Cao B, Wang C. 
Evaluation of the efficacy and safety of intravenous remdesivir in adult patients with severe COVID-19: study protocol for a phase 3 randomized, double-blind, placebo-controlled, multicentre trial. Trials. 2020;21(1):422. doi: 10.1186/s13063020-04352-9, PMID 32448345.

69. Ah A, ST Z. Preprocessing of the Candidate Antiviral Drugs against COVID-19 in models of SARS cov2 Targets. LA: Prensa Medica Argentina; 2020. p. 106.

70. Yao TT, Qian JD, Zhu WY, Wang Y, Wang GQ. A systematic review of lopinavir therapy for SARS coronavirus and MERS coronavirus-A possible reference for coronavirus disease-19 treatment option. J Medical Virology. 2020;92(6):556-63. doi: 10.1002/jmv.25729, PMID 32104907.

71. Chen J, Hu C, Chen L, Tang L, Zhu Y, Xu X, Chen L, Gao H, Lu X, Yu L, Dai X, Xiang C, Li L. Clinical study of mesenchymal stem cell treatment for acute respiratory distress syndrome induced by epidemic influenza A (H7N9) infection: A hint for COVID-19 treatment. Engineering (Beijing). 2020;6(10):1153-61. doi: 10.1016/j.eng.2020.02.006, PMID 32292627.

72. Ali I, Alharbi OML. COVID-19: Disease, management, treatment, and social impact. Science of The Total Environment. 2020;728:138861:138861. doi: 10.1016/ j.scitotenv.2020.138861.

73. Dong $\mathrm{L}, \mathrm{Hu} \mathrm{S}$, Gao J. Discovering drugs to treat coronavirus disease 2019 (COVID-19). Drug Discoveries and Therapeutics. 2020;14(1):58-60. doi: 10.5582/ddt.2020.01012, PMID 32147628.

74. Favalli EG, Biggioggero M, Maioli G, Caporali R. Baricitinib for COVID-19: a suitable treatment? The Lancet Infectious Diseases. 2020;20(9):1012-13. doi: 10.1016/S14733099(20)30262-0, PMID 32251638.
75. Colson P, Rolain JM, Lagier JC, Brouqui P, Raoult D. Chloroquine and hydroxychloroquine as available weapons to fight COVID19. International Journal of Antimicrobial Agents. 2020;55(4):105932. doi: 10.1016/j.ijantimicag.2020.105932.

76. Cortegiani A, Ingoglia G, Ippolito $M$, Giarratano A, Einav S. A systematic review on the efficacy and safety of chloroquine for the treatment of COVID-19. Journal of Critical Care. 2020;57:279-283. doi: 10.1016/j.jcrc.2020.03.005, PMID 32173110.

77. Cao Y. Suggestion using alcohol vaporization or nebulization inhalation therapy for pneumonitis caused by coronavirus. SRN Journal. 2020. doi: 10.2139/ssrn.3545744.

78. Ago H, Adachi T, Yoshida A, Yamamoto M, Habuka N, Yatsunami K, Miyano M. Crystal structure of the RNA-dependent RNA polymerase of hepatitis C virus. Structure. 1999;7(11):141726. doi: 10.1016/s0969-2126(00)80031-3, PMID 10574802.

79. Kouznetsova VL, Zhang A, Tatineni M, Miller MA, Tsigelny IF. Potential COVID-19 papain-like protease PLpro inhibitors: repurposing FDA-approved drugs. Peer J. 2020;8:e9965. doi: 10.7717 /peerj.9965, PMID 32999768.

80. Iyer M, Jayaramayya K, Subramaniam MD, Lee SB, Dayem AA, Cho SG, Vellingiri B. COVID-19: an update on diagnostic and therapeutic approaches. BMB Reports. 2020;53(4):191-205. doi: 10.5483/BMBRep.2020.53.4.080, PMID 32336317.

81. Boopathi S, Poma AB, Kolandaivel P. Novel 2019 coronavirus structure, mechanism of action, antiviral drug promises and rule out against its treatment. Journal of Biomolecular Structure and Dynamics. 2020;1-10. doi: 10.1080/07391102.2020.1758788.

82. Zhai P, Ding Y, Wu X, Long J, Zhong Y, Li Y. The epidemiology, diagnosis and treatment of COVID-19. International Journal of Antimicrobial Agents. 2020;55(5):105955. doi: 10.1016/ j.ijantimicag.2020.105955. 